
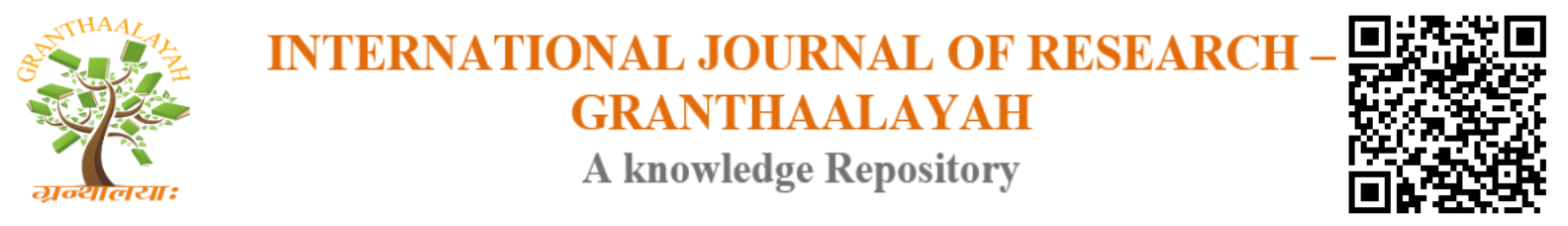

Social

\title{
QUALITY CULTURE OF ISLAMIC BOARDING SCHOOL
}

\author{
Dr. Abd. Muhith *1 \\ ${ }^{* 1}$ Lecture, The State Institute for Islamic Studies Jember
}

\begin{abstract}
The existence and role of Islamic boarding schools in the field of social life of the community requires serious attention. Proper management and provision and improvement of human resources in the field of management. Inequality between large boarding schools and small Islamic boarding schools is clearly seen in the management of pesantren.

Culture is an obstacle in conducting pesantren activities. The quality of pesantren is formulated based on management which is carried out in a tangible process starting from planning, organizing, implementing and monitoring carried out to determine or resolve predetermined goals using people and other resources.

This type of research uses ethnography with qualitative research methods with descriptive analysis. The research findings focused on pesantren quality culture models that formulated the problem in more detail so that researchers used a qualitative approach with an in-depth interview observation. The conclusion of the results of this study is the quality of pesantren culture embodied in the form of organizational culture that is used as a system of values, beliefs, assumptions, or norms that have been applied, agreed upon and followed by members of the organization as a code of conduct for pesantren activities, madrasas and schools.
\end{abstract}

Keywords: Pesantren; Quality Culture; Management.

Cite This Article: Dr. Abd. Muhith. (2018). "QUALITY CULTURE OF ISLAMIC BOARDING SCHOOL." International Journal of Research - Granthaalayah, 6(10), 25-37. https://doi.org/10.5281/zenodo.1473814.

\section{Introduction}

Islamic boarding school is one of the models of Islamic education that has been active in Indonesia for a long time and its benefits have been widely felt by this nation, facing a number of serious challenges, both in terms of education, economics, politics and culture. Islamic boarding schools have a very large influence to participate in achieving the ideals of national education whose functions and objectives are as follows:

National education functions to develop the ability and shape of dignified national character and civilization in order to educate the life of the nation, aims to develop the potential of students to become faithful and fearful people of God Almighty, noble, healthy, knowledgeable, capable, 
creative, independent, and become a democratic and responsible citizen (Republic of Indonesia Law, no. 20 of 2003)

The functions and objectives of national education will be achieved if all educational institutions in Indonesia continue to be developed in quality. The task of improving the quality of human resources in creating the younger generation is not only played by the government through formal schools and islamic shcool, on the other hand the external elements such as Islamic boarding schools as the oldest Islamic education institutions in Indonesia also have a big role in educating the lives of the nation (Suheri: 2018) This includes pesantren education. The efforts to develop the quality have been carried out by the government with various programs, both policy and guidance, but the policy tools and other stimulant programs are not enough, without any efforts from internal organizations including the islamic boarding shcool organization. Therefore, the most interesting issue today in relation to education is the effort to improve the quality of education.

Following up on this effort, the government issued regulation number 63 of 2009 concerning the quality assurance system for education including in this context is a process of improving the quality of Islamic education. Efforts to improve the quality of education ultimately lead to a demand for education to continue to make improvements that will be substantially relevant to changes in the values, norms, paradigms and needs of the community itself. This fact is said by some people that the quality of education can be massively increased if handled effectively and efficiently with an integrated managerial pattern. That is, various sources that influence the occurrence of the educational process need to be carried out in a clear, controlled, directed and measurable manner with standard. This also applies to the Islamic education system which in the development and change of society demands that the education system can develop sustainably with the community while being able to play its role in society. In order to develop the quality of Islamic education including islamic boarding school education, of course the need for a quality culture must be carried out in a consistent and consistent manner.

The aim of national education must be a barometer of educational institutions in the entire territory of the Republic of Indonesia's unitary state in determining its educational goals. Islamic Boarding Schools are one type of education, not only required to focus on the quality of education, but must be an agent of quality culture, because Islamic boarding schools are educational institutions that must carry out a process of civilizing and empowering students that lasts for life and the crater upfront to create the righteous generation as the pioneer of the process of civilization and empowerment on earth, as analyzed from the word of God as follows:

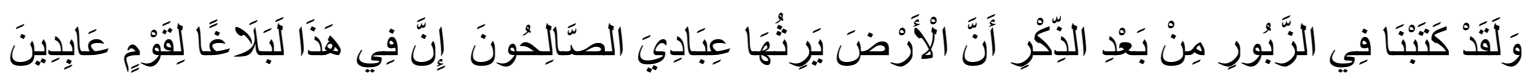

Meaning: and indeed We have written in Zabur after (we write in) Lauh Mahfuzh, that this earth was destroyed by my righteous servants. Verily (what is mentioned) in this (Letter) really becomes a warning to the people who worship (Allah)

The boarding school is one of the models of Islamic education, has the responsibility to provide provisions to grow the righteous generation starting from teaching reading, writing, providing the basics of self-purification in the form of the teachings of the faith, Shari'a, and morals, the Qur'an, hadith, and knowledge that makes skilled to deal with problems in the world as a provision in the 
next life. The activity was adopted by the Islamic boarding school from the word of God in the Quran:

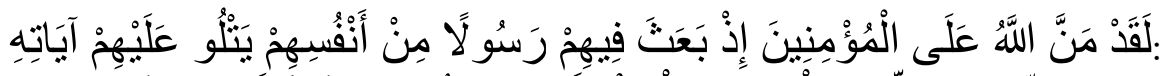

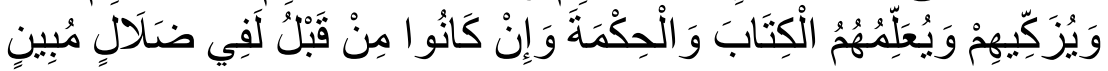

Meaning: truly God has given gifts to those who believe when God sends among them an Apostle from their own group, who reads to them the verses of Allah, cleanses (their souls), and teaches them the Book and the Wisdom. and indeed before (the coming of the Prophet) they were truly in real error.

These activities are not just routines, but have the investment value of worship that continues to flow to make social changes whose rewards will continue to be picked up as long as the next genasi is preserved as the Prophet Muhammad said:

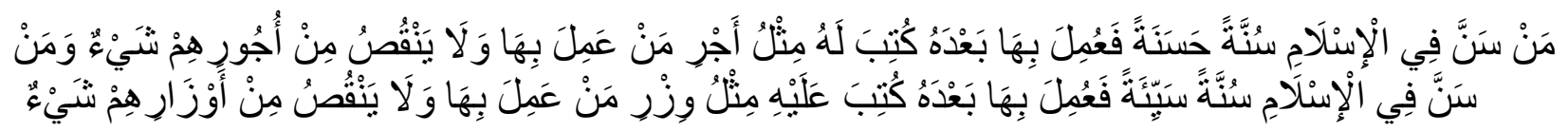

Meaning: "Whoever preserves a good footprint in Islam, then follows afterwards, then he gets the reward of the person who does it without reducing the reward of the culprit, and whoever preserves the bad footprint in Islam, then is done by others afterwards, then he will get the sins of people who do it without reducing any of their sins. Quality culture is one of the objectives of the implementation of education quality assurance in the territory of the Republic of Indonesia, which is the establishment of a culture of formal, non-formal and / or informal education quality (Muslim; 465).

At the practical level, many Islamic boarding schools have been shown to have lost their identity, thus forgetting the main task as an institution to prepare the basis for deepening religious knowledge, as well as being a place to prepare an independent human being, leaving no sense of civilization that sometimes contradicts Islamic values, whether planned or not. We can prove this situation in the organization of end of year conducted every year by the Islamic boarding school. Meanwhile, there are pesantren that have a quality culture according to their resources, their geographical location, vision and mission. Among them are the boarding school of Sidogiri Pasuruan, the Islamic boarding school has a peculiarity in carrying out a quality culture, so the pesntren cottage has its own place in the hearts of the people of East Java.

\section{Method}

Ethnography is the method that researchers use in this study. Ethnography is a systematic representation and analysis of a group culture, society or ethnic group that is gathered from the field in the same time period (Bungin, 2012: 181).

Ethnographic studies (ethnographic studies) describe and interpret culture, social groups or systems. Although cultural meaning is very broad, ethnographic studies are usually focused on patterns of activity, language, beliefs, rituals and ways of life (Sukmadinata, 2006: 62). Ethnography is a type of 
qualitative research, where researchers conduct a study of group culture in natural conditions through observation and interviews. (Creswell in Sugiyono, 2012: 229).

Furthermore, the approach that researchers use in this research is qualitative which means that research is based on the philosophy of postpositivism (interpretive), used to examine the condition of natural objects, (natural settings) where researchers are key instruments (Sugiyono, 2014: 235).

Data is the result of recording the research both in the form of descriptive notes and numbers (Arikunto, 2002: 96). The data in this study are (1) the results of interviews by researchers and caregivers of Islamic boarding schools, administrators of boarding schools, students, and religious teachers in Islamic Boarding School Sidogiri Pasuruan. (2) results of observations or observations related to all activities observed by researchers. (3) documents, namely data in the form of archives, and other supporting documents.

Data sources are anything or someone who can provide information about research data. Based on the source, the data are divided into two, namely primary data and secondary data. Primary data is data collected by researchers directly from the first source or place of research object. In this case the researcher conducted interviews and made observations related to the problem being studied, both with Kiai, Asatidz, Management, students and the conditions of the boarding school field. In addition to primary data, the data sources used by researchers are secondary data sources, secondary data obtained through various sources, namely the article literature, and sites on the internet relating to research conducted (Sugiyono, 2009: 137; Suheri: 2017).

The primary data above in qualitative research comes from words and actions written through video recording / audio tapes, taking photos, or films. Observation of data sources through interviews or observations is the result of a combined effort from the activities of researchers seeing, hearing, and asking questions (Moleong, 2014: 157). The data collection referred to by the researcher is the method used by the researcher in obtaining the expected data. Collecting data in research using interview, observation and documentation techniques.

The interview technique used in qualitative research is in-depth interviews, namely the process of obtaining information for research purposes by asking questions and answers face to face between the interviewer and the informant or interviewee, with or without the use of interview guides, in where the interviewer and the informant are involved in a relatively long social life (Sutopo, 2006: 72).

\section{Result and Discussion}

The era of technology and information is progressing rapidly so that the world seems to be getting smaller, the boundaries between countries that become insulating are no longer there. Communication between nations is not distant so that interaction between groups that have different cultures is faster and younger, it can cause one country group to emulate the culture of another country group.

The tendency of global behavior mentioned above, is a thing that cannot be denied, but the environment of a group of people living and socializing for a long time remains an important factor that influences a person's mindset and action, so that the phenomenon of global behavior will not completely change towards a community group that has characteristics that are adhered to by the 
environment in which it lives, the culture that they preserve and with whom it associates that distinguishes it from other groups (Shobirin: 2009).

From this brief description, it can be concluded that the strength of a group's culture is so strong that it cannot be easily eroded by the culture of other groups, thus the Islamic boarding school Ibtidayah because of the educational institutions that have to carry out a process of civilization and empowerment of students that lasts a lifetime has an important meaning for learned and understood.

\subsection{Concept of Quality Culture at Islamic Boarding Schools}

According to Glimer, that the organizational climate is the characters that distinguish an organization from other organizations and affect the people in it (Glimer:1966). Whereas according to Litein and Robert that organizational climate is a series of measurable properties in a work environment based on the perception of a group of people who live and work in the environment and are shown to influence behavior (Litein and Robert:1968).

Organizational culture can be summed up as a system of values, beliefs, assumptions, or norms that have been applied, agreed upon and followed by members of the organization as guidelines for behavior and solving various problems his organization (Sutrisno: 2014).

In the context of Islamic boarding schools, quality culture is a system of values, beliefs, assumptions, or norms that have prevailed in pesantren, agreed upon and followed by residents of Islamic boarding schools as guidelines behavior and solving various problems in the boarding school, to maintain quality. Because the quality culture of a strong boarding school is very significant to support the goals of the islamic boarding school cottage to achieve excellence, on the contrary the weak culture of the islamic boarding school will hamper the islamic boarding school to achieve its goals (Sutrisno: 2014).

Organizational Climate Elements are: 1) leadership, 2) motivation and 3) job satisfaction of all organizational stake holders. Climate (Health) Organization According to Hoy \& Miskel (2001) there are three levels of organizational climate (relation to education), namely:

1) Level Institusional: relating to the Islamic boarding school environment, where Islamic boarding schools can overcome their environment by strengthening the integrity of educational programs, so that administrators and clerics are protected from irrational demands from students and parents.

2) Level Administrative (collegal leadership): related to the managerial function of the organization, where things are shown by leaders and administrators of boarding schools that are friendly, supportive, open, and in accordance with existing norms.

3) Teacher Level: relating to the teaching and learning process, this consists of two things:

4) Teacher Affiliation, feelings of friendship and brotherhood of the teacher and strong ties with the pesntren cottage. The religious teachers feel comfortable with the pesantren environment.

5) Academic Emphasis (academic attention), Islamic boarding schools are directed to achieve academic achievement and can be achieved by students. This needs to be established with 
a regular learning environment, the cleric believes in the ability of students to excel and students learn hard to get good academic performance (Arcaro: 2007).

Furthermore, the characteristics of Islamic boarding schools that lack attention to quality culture are:

1) Islamic boarding school environment is easily attacked by destructive external forces

2) religious teachers and administrators are attacked by irrational demands of parents

3) low institutional integrity

4) the board and board of the pesntren cottage are less effective and give little direction and are less able to influence

5) Ustadz do not like their colleagues and work

6) closeness and brotherhood among clerics are weak

7) teaching materials and supporting materials are not available

8) attention to academic achievement is minimal

9) santri who have underappreciated achievements are even seen as a threat by the teacher, and others.

The climate of islamic boarding school organization is the total quality of the environment used in Islamic boarding school education organizations. The building forms of this school organization are:

1) open-closed model

2) healthy - sick school

3) Report on the community of Islamic boarding schools

4) Student control ideology (Hasan: 2010)

\subsection{Quality of Cultural Quality of Islamic Boarding Schools}

Each organization has its own uniqueness, the uniqueness can be an advantage characteristic in the organization, among several characteristics in an organization are the primary values that are owned, if the primary values can be packaged properly as a guide for acting and working in organizations, then the organization can be a positive organizational culture.

There are various primary values that must be possessed by an organization according to Miller, primary values or some of these cultural values can also be referred to as principles, these principles consist of eight points, namely: principles, goals, consensus, excellence, achievement, unity, empirical, intimacy and integrity (Sobirin: 2017).

Thus the cultural value of the quality of Islamic boarding schools in addition to having eight points, namely: principles, goals, consensus, excellence, achievement, unity, empirical, intimacy, and integrity that are not contrary to the teachings of Islam.

\subsubsection{Implementation of Islamic Boarding School Culture}

The application of quality culture in an organization, including Islamic boarding schools can be done as follows: 


\section{Socialization}

The strategy for the implementation of quality culture at Islamic boarding schools can be done through socialization, in this strategy the leaders and management of the islamic boarding school hut can take cultural manipulation by directing all boarding school residents to make positive contributions and not to have a negative influence.

Socialization is a process of transforming Islamic boarding school residents to effectively participate in the quality culture of Islamic boarding schools, so that individual residents of Islamic boarding schools experience an active change and can integrate the objectives of the Islamic boarding school with the aim of boarding school residents through the stages of communication, interaction and participation. Socialization can involve micro issues and even macro issues (Sutrisno: 2009).

\section{Empowerment Culture}

The rapid changes in the global environment affect all fields, including educational institutions such as Islamic boarding schools, these conditions give rise to an action-reaction pattern of an organization including Islamic boarding schools to transform, transformation needs to achieve competitive advantage can be done through structural and cultural transformations, but residents of Islamic boarding schools must understand the transformation in detail and depth, so that it can make changes effectively, efficiently, and avoid counter-productive (Sallis: 74).

In an empowerment culture must understand the following:

1) Creating an Empowerment Environment In creating an empowerment environment can be done by forming work teams and sharing information, training the necessary resources, measurement, feedback, and reinforcement.

2) Model of Empowerment of Human Resources Empowerment can be done by selecting the following models:

- Desire, familiarize themselves with initiative, delegate, and involve employees

- Trust, share information and suggestions without worry;

- Confidence, expressing the description of the ability of the employee

- Credibility, consistency of actions with speech to maintain a good work environment;

- Accoutability, set rules, standards and assessments consistently and clearly.

- Communication, generating understanding among employees (Sutrisno: 2014).

3) Empowerment as a Cultural Change

Empowerment as an effort to make cultural changes can be effective if communicated with all boarding school residents, so as to produce the following:

- Increase productivity;

- Develop an attitude of responsibility; and

- Delegate greater authority to all residents of Islamic boarding schools.

- The role of interpersonal interventions in dissemination

Empowerment is basically a personal interaction that provides mutual benefits based on an attitude of understanding, openness, honesty, and mutual need between leaders and all members in the organization to make continuous improvements in service and productivity to consumers. To empower effectively, quickly, and detected, it can empower by using resources within the organization itself. Empowerment as mentioned above is an interpersonal intervention, while 
interpersonal interventions can have an important role if designed with a participatory model, as follows:

"This interpersonal intervention plays an important role in empowerment carried out in the company if it is supported by a more participatory organizational design. Participatory design is an approach that requires people to participate in planning and restructuring their own management and multi-skilling in their workplace (Sutrisno: 63).

Participatory empowerment design can encourage a very significant change, because it is done by involving all members in the organization who have an interest in achieving success in achieving common goals and individual aspirations.

In the context of the Islamic boarding school, participatory empowerment can be done by assigning responsibility to all to participate in empowering Islamic boarding schools by involving themselves in empowering and empowering each other, in accordance with their respective potential and competencies by alternating to become inspiration and resource persons in empowerment activities. , so that all residents of the Islamic boarding school become productive (Sutrisno: 64)

Islamic boarding schools that use participatory design in empowerment will be more focused on achieving a quality culture, because the coordination of Islamic boarding school residents in various levels to achieve productivity is caused by their responsibilities with multi skills to meet internal and external demands. While the strength of the democratic structure is in the form of their responsibility towards the Islamic boarding school environment which is human capital. To achieve success in participatory empowerment can use the following design mix models:

- Ensuring and clarifying the division of authority and responsibility needed in changing the quality culture in Islamic boarding schools towards empowering human resources.

- Team works with various skills.

- Creating a mechanism to reduce the resistance to changes.

- Save time and power to develop workplaces.

Participatory empowerment at the Islamic boarding school essentially is to build a climate of mutual benefit through interpersonal interaction with the principles of mutual trust, openness, and mutual respect with designs that integrate the vision, structure, and change of pesantren's culture better in individuals and groups of Islamic boarding schools that produce culture effective and efficient quality (Ilyasin \& Nanik Nurhayati: 2012).

\subsection{Quality System Standards}

Among the various important factors in the appearance of Islamic boarding schools is the quality of services produced from its services, resources, output, and outcame. Quality can be something abstract and can be simplified to be congruent. The quality of abstract Islamic boarding schools, for example: reliable resources, the best graduates, skilled teachers, adequate facilities and so on. Quality can also be simplified by following a congruent definition, because there are several indicators that accompany it, such as interpreunership Islamic boarding school with accompanying indicators. All of the definitions of quality are the satisfaction of boarding school users (Sallis: 2002). 
The quality standard used by Islamic boarding schools must be determined from the beginning, so that the quality of the boarding school can be measured. While Islamic boarding schools are a type of education regulated by the Law of the Republic of Indonesia national education system, is an educational institution that has its own characteristics and determines which is the peculiarity of the Islamic boarding school.

From the description above, it is increasingly clear that the standard quality system of Islamic boarding schools is at a minimum must:

1) In accordance with the needs of the times faced;

2) Meeting the needs of service users;

3) In accordance with specifications or standards (National or International) in accordance with the selected standards.

4) In accordance with the provisions of the applicable law.

The efforts carried out by the Islamic boarding school to achieve the standards set include efforts to:

1) 1). Achieve, maintain, and improve the quality of services, resources and graduates;

2) Giving confidence to the residents of the Islamic boarding school that the desired quality is achieved, maintained and improved; and

3) Convincing Islamic boarding school users that the expected quality can be achieved (Ahmad: 1996).

These three efforts must be coordinated in depth, continuously, and consistently so as to produce a quality boarding school strategic plan, because the process of planning, implementing, evaluating and following through through market research, service development engineering, procurement of program activities, services and resources power, planning and development, processes, supervision and evaluation, standard operational procedures, and determination of graduation.

\subsection{Mechanism of Cultural Change}

To achieve a better change the main factor is the top management commitment, because the highest authority and the hardest responsibility is on their shoulders, the top leaders' commitment to make better changes needs to get the support that is balanced with the leader's attitude to consistently show the behavior and activities that in accordance with the vision of organization. Furthermore, the mysticism of cultural change can be seen in the following table:

Table 1: Mechanism of Cultural Change

\begin{tabular}{|l|l|l|l|}
\hline No & Focus & From Traditional Culture to & Quality Cultural Management \\
\hline 1 & Plan & Short term budget & Future strategic issues \\
\hline 2 & Organization & $\begin{array}{l}\text { Hierarchy based on chain of } \\
\text { command }\end{array}$ & $\begin{array}{l}\text { Employee participation and } \\
\text { empowerment }\end{array}$ \\
\hline 3 & Control & Variant report & $\begin{array}{l}\text { Size and quality information for self- } \\
\text { control }\end{array}$ \\
\hline 4 & Communication & Top-down & Top down and botton-up \\
\hline 5 & Decision & Crisis management & Planned changes \\
\hline 6 & Management & Parachial, competitive & Cross-funcion, integrative \\
\hline
\end{tabular}




\begin{tabular}{|l|l|l|l|l|}
\hline 7 & $\begin{array}{l}\text { Quality } \\
\text { Management }\end{array}$ & $\begin{array}{l}\text { Fizing or one-shot } \\
\text { manufacturing }\end{array}$ & $\begin{array}{l}\text { Prevebtive and sustainable all } \\
\text { functions and quality }\end{array}$ & \\
\hline
\end{tabular}

From the table, it can be understood the mysticism of cultural change, however, in making cultural changes it is necessary to pay attention to the following:

- History of the creation of an existing culture;

- Not hostile to the existing system, but will make improvements;

- Willingness to listen and observe; and

- Show everyone who is affected by change (Ahmad: 1996).

From the explanation it is clear that, making changes needs to be prepared and prepared so that there will be no failures in the internal organization, so that the efforts can be carried out because they are supported by competence and carried out with the team.

Thus, the implementation of quality culture at Islamic boarding schools is done through:

Socialization is a process of transforming Islamic boarding school residents to effectively participate in the quality culture of Islamic boarding schools, so that individual residents of Islamic boarding schools experience an active change and can integrate the objectives of the Islamic boarding school with the aim of boarding school residents through the stages of communication, interaction and participation. Socialization can be related to micro issues and even macro issues.

Participatory empowerment at the Islamic boarding school essentially is to build a climate of mutual benefit through interpersonal interaction with the principles of mutual trust, openness, and mutual respect with designs that integrate the vision, structure, and change of pesantren's culture better in individuals and groups of Islamic boarding schools that produce culture effective and efficient quality.

Establishing a standard quality system standard for the quality system of a boarding school in essence must at a minimum:

1) In accordance with the needs of the times faced;

2) Meeting the needs of service users;

3) In accordance with specifications or standards (National or International) in accordance with the selected standards.

4) In accordance with the provisions of the applicable law.

The efforts made by the Islamic boarding school to achieve the stipulated standard include efforts to:

1) Achieve, maintain and improve the quality of services, resources and graduates;

2) Providing confidence to the residents of the Islamic boarding school that the desired quality is achieved, maintained and improved; and

3) Convincing boarding school users that the expected quality can be achieved Making mechanisms for change in culture

Making cultural changes needs to pay attention to the following:

1) History of the creation of an existing culture;

2) Not hostile to the existing system, but will make improvements; 
3) Willingness to listen and observe; and

4) Show everyone affected by change

\subsection{Impact of Quality Culture at Islamic Boarding Schools}

The process of meaning (interpretation) of the phenomena, events, and activities of Islamic boarding schools should not be subjective, which is only understood by the elite of the boarding school, but must be communicated and internalized to every Islamic boarding schools residents in order to become a culture and meaning system that is understood, imbued, and practiced together by all boarding school residents. So that it is not only understood with something that is visible (overt), such as strategy, structure, organizational system, and job description. Because this is only a manifestation of the identity and culture of Islamic boarding schools (Wibisono: 2006).

Thus, the culture of the Islamic boarding school is a set of assumptions that are considered very important even though it is not written which is understood by all residents of the boarding school, as analyzed by the definition of the organization presented by Stanley Davis as follows:

"Corporate culture is the pattern of shared beliefs and values that give members of an institution meaning, and provide them with the rules for behavior in thier organization" corporate culture is shared beliefs and values that give meaning to members of an institution and make beliefs and this value as a rule / guideline to behave within the organization"

From this definition organizational culture is a guide to speak and act in organizations that can have an impact on effectiveness, innovation, loyalty, and productivity, the four impacts of organizational culture in detail can be described below:

a. Work motivation;

b. Attitude and commitment to work;

c. Influencing employee-oriented leadership processes (humanistic leadership);

d. Decision making process;

e. How to communicate;

f. How to build an organizational structure;

g. Employee performance;

h. Organizational productivity;

i. Insights into excellence (through managers who have a competitiveness \& comparativeness philosophy);

j. Joblessness and job satisfaction;

k. Sense of belonging \& sense of responsibility.

1. A conducive work climate (Muhith: 2013).

\section{Conclusion}

Quality culture is a system of values, beliefs, assumptions, or norms that have prevailed in Islamic boarding schools, agreed upon and followed by residents of Islamic boarding schools as behavioral guidelines and solutions various problems in the boarding school, to maintain quality. There are various primary values that must be possessed by an organization according to Miller, primary values or some of these cultural values can also be called by principle, principles of implementation 
of quality culture in Islamic boarding schools are carried out through socialization which is a process of transforming pesantren residents to participate in effective against the quality culture of Islamic boarding schools, so that individual residents of Islamic boarding schools experience an active change and can integrate the objectives of the boarding school with the aim of the Islamic boarding school residents through the stages of communication, interaction and participation. Socialization can be related to micro issues and even macro issues. In addition, participatory provision in Islamic boarding schools essentially is to build a climate of mutual benefit through interpersonal interaction with the principles of mutual trust, openness, and mutual respect with designs that integrate the vision, structure, and change of pesantren's culture better in individuals and groups of Islamic boarding schools. produce an effective and efficient quality culture. The standard quality system of Islamic boarding schools in essence must be at least in accordance with the needs of the times faced; Meet the needs of service users; In accordance with specifications or standards (National or International) in accordance with the selected standards. Islamic boarding school culture is a guide to speak and act in organizations that can have an impact on effectiveness, innovation, loyalty, and productivity, with the impact of organizational culture on work motivation; Attitude and commitment to work; Influencing employee-oriented leadership processes (humanistic leadership); Decision making process.

\section{References}

[1] Ahmad Sobirin, 2009, Budaya Organisasi, Yogyakarta, Unit Penerbit dan Percetakan STIM YKPN

[2] Departemen Agama, 2000, Al-Qur'an dan terjamahnya, Jakarta: Diponegoro

[3] Edy Sutrisno, 2011. Budaya Organisasi. Jakarta: Kencana Prenada Media Group.

[4] Edward Sallis, 2014, Total Quality Management in Education, Jogjakarta: IRCiSoD.

[5] Fandy Tjiptono \& Anastasia Diana, 2009, Total Quality Management (TQM), Yogyakarta: Andi.

[6] Hadari Nawawi, Manajemen Strategik Organisasi Non-Profit Bidang Pemerintahan Dengan Ilustrasi di Bidang Pendidikan, Yogyakarta: Gadjah Mada University Press.

[7] Haidar Putra Daulay, 2012, Pendidikan Islam dalam Sistem Pendidikan Nasional di Indonesia, Jakarta: Kencana

[8] Idrus fahmi.tt. 2012, Kamus Lengkap Bahasa Indonesia, Surabaya: Greisinda Press.

[9] Jens J.Dahlgaard, Kai Kristensen, and Gopal K.Kanji, 1998, Fundamentals of Total Quality Management, Taylor \& Francis: First Published.

[10] Jerome, S. Arcaro, 2007, Pendidikan Berbasisi Mutu Prinsip Perumusan dan Langkah Penerapan. Diterjemahkan oleh Yosal Iriantara, Yogyakarta: Pustaka Pelajar.

[11] Muhaimin, 2008. Paradigma Pendidikan Islam. Bandung, Remaja Rosda Karya.

[12] Muslim, Shahih Muslim, Surabaya: al-Hidayah.

[13] Sugiyono. 2012. Metode penelitian kuantitatif, kualitatif, dan R \& D. Bandung: Alfabeta.

[14] Syaefudin Sa'ud, udin \& Abin Syamsuddin Makmur. 2009. Perencanaan Pendidikan. Bandung: Remaja Rosdakarya

[15] Sekretaris Kementerian Agama RI, Peraturan Menteri Agama Nomor 90 Tahun 2013 tentang Penyelenggaraan Pondok pesantren, Jakarta.

[16] Ramayulis, Ilmu Pendidikan Islam (Jakarta: Kalam Mulia, 2011).

[17] Said Hamid Hasan DKK, Pengembangan Pendidikan Budaya dan Karakter Bangsa, (Badan Litbang Kemendiknas: Jakarta, 2010)

[18] Umiarso dan Nurr Zazin, Pesantren di Tengah Arus Mutu Pendidikan (Semarang: Rasail: 2011)

[19] Umiarso \& Imam Gojali, Manajemen Mutu Sekolah di Era Otonomi Pendidikan: "Menjual" Mutu Pendidikan Dengan Pendekatan Quality Control bagi Pelaku Lembaga Pendidikan, (Yogyakarta: IRCiSoD, 2010)

[20] UU RI, Sistem Pendidikan Nasional, nomor: 20, tahun 2003. 
[21] Suheri, S., \& Nurrahmawati, Y. T. (2018). Model Pendidikan Multikultural Di Pondok Pesantren. Pedagogik: Jurnal Pendidikan, 5(1), 32-49

[22] Suheri, S., \& Nurrahmawati, Y. T. (2018, April). Desain Pendidikan Multikultural di Pondok Pesantren Salaf Kauman Alhasani Allathifi Bondowoso. In PROCEEDINGS: Annual Conference for Muslim Scholars (No. Series 2, pp. 663-672).

[23] Suheri, S. (2017, May). Adversity Quotient di Pesantren. In PROCEEDINGS: Annual Conference for Muslim Scholars (No. Seri 2, pp. 591-597).

[24] Suheri,

[25] Wahyudin, Dinn. Manajemen Kurikulum, Bandung: PT. Remaja Rosdakarya, 2014.

*Corresponding author.

E-mail address: suheri.lpdp@gmail.com 